\title{
Relationship between water and aragonite barium concentrations in aquaria reared juvenile corals
}

\author{
Meagan Eagle Gonneea ${ }^{\mathrm{a}, *, 1}$, Anne L. Cohen ${ }^{\mathrm{b}}$, Thomas M. DeCarlo ${ }^{\mathrm{c}, 2}$, \\ Matthew A. Charette ${ }^{d}$ \\ ${ }^{\mathrm{a}}$ Woods Hole Coastal \& Marine Science Center, U.S. Geological Survey, 384 Woods Hole Rd., Woods Hole, MA 02543, USA \\ ${ }^{\mathrm{b}}$ Department of Marine Geology \& Geophysics, Woods Hole Oceanographic Institution, 266 Woods Hole Rd., Woods Hole, MA 02543, USA \\ ${ }^{\mathrm{c}}$ ARC Centre of Excellence for Coral Reef Studies, School of Earth Sciences and Oceans Institute, The University of Western Australia, \\ Crawley, WA, Australia \\ ${ }^{\mathrm{d}}$ Department of Marine Chemistry \& Geochemistry, Woods Hole Oceanographic Institution, 266 Woods Hole Rd., Woods Hole, \\ MA 02543, USA
}

Received 2 June 2016; accepted in revised form 3 April 2017; available online 9 April 2017

\begin{abstract}
Coral barium to calcium $(\mathrm{Ba} / \mathrm{Ca})$ ratios have been used to reconstruct records of upwelling, river and groundwater discharge, and sediment and dust input to the coastal ocean. However, this proxy has not yet been explicitly tested to determine if $\mathrm{Ba}$ inclusion in the coral skeleton is directly proportional to seawater Ba concentration and to further determine how additional factors such as temperature and calcification rate control coral $\mathrm{Ba} / \mathrm{Ca}$ ratios. We measured the inclusion of $\mathrm{Ba}$ within aquaria reared juvenile corals (Favia fragum) at three temperatures $\left(\sim 27.7,24.6\right.$ and $22.5^{\circ} \mathrm{C}$ ) and three seawater Ba concentrations $\left(73,230\right.$ and $\left.450 \mathrm{nmol} \mathrm{kg}^{-1}\right)$. Coral polyps were settled on tiles conditioned with encrusting coralline algae, which complicated chemical analysis of the coral skeletal material grown during the aquaria experiments. We utilized $\mathrm{Sr} / \mathrm{Ca}$ ratios of encrusting coralline algae (as low as $3.4 \mathrm{mmol} \mathrm{mol}^{-1}$ ) to correct coral $\mathrm{Ba} / \mathrm{Ca}$ for this contamination, which was determined to be $26 \pm 11 \%$ using a two end member mixing model. Notably, there was a large range in $\mathrm{Ba} / \mathrm{Ca}$ across all treatments, however, we found that $\mathrm{Ba}$ inclusion was linear across the full concentration range. The temperature sensitivity of the distribution coefficient is within the range of previously reported values. Finally, calcification rate, which displayed large variability, was not correlated to the distribution coefficient. The observed temperature dependence predicts a change in coral $\mathrm{Ba} / \mathrm{Ca}$ ratios of $1.1 \mu \mathrm{mol} \mathrm{mol}{ }^{-1}$ from 20 to $28^{\circ} \mathrm{C}$ for typical coastal ocean Ba concentrations of $50 \mathrm{nmol} \mathrm{kg}^{-1}$. Given the linear uptake of Ba by corals observed in this study, coral proxy records that demonstrate peaks of $10-25 \mu \mathrm{mol} \mathrm{mol}^{-1}$ would require coastal seawater $\mathrm{Ba}$ of between 60 and $145 \mathrm{nmol} \mathrm{kg}^{-1}$. Further validation of the coral $\mathrm{Ba} / \mathrm{Ca}$ proxy requires evaluation of changes in seawater chemistry associated with the environmental perturbation recorded by the coral as well as verification of these results for Porites species, which are widely used in paleo reconstructions.
\end{abstract}

Published by Elsevier Ltd.

Keywords: Coral Ba/Ca; Barium; Aragonite; Distribution coefficient; Favia fragum

\footnotetext{
* Corresponding author.

E-mail addresses: mgonneea@usgs.gov (M.E. Gonneea), acohen@whoi.edu (A.L.Cohen), thomas.decarlo@uwa.edu.au (T.M. DeCarlo), mcharette@whoi.edu (M.A. Charette).

${ }^{1}$ Formerly at, Department of Marine Chemistry \& Geochemistry, Woods Hole Oceanographic Institution, 266 Woods Hole Rd., Woods Hole, MA 02543, USA.

${ }^{2}$ Formerly at, Department of Marine Geology \& Geophysics, Woods Hole Oceanographic Institution, 266 Woods Hole Rd., Woods Hole, MA 02543, USA.
} 


\section{INTRODUCTION}

Coral inclusion of barium $(\mathrm{Ba})$ has been linked to changes in ocean chemistry with variability in coral $\mathrm{Ba} /$ $\mathrm{Ca}$ implicated as a climate proxy of river discharge, river sediment transport, upwelling, and groundwater discharge (itself a rainfall proxy) (Table 1 and references therein). Reconstruction of such environmental records provides valuable insight into past climate conditions. The utility of the coral $\mathrm{Ba} / \mathrm{Ca}$ proxy stems from several factors. First, $\mathrm{Ba}$ readily substitutes for $\mathrm{Ca}$ within the aragonite skeleton due to similar ionic radii. Second, terrestrial water and sediment sources have elevated $\mathrm{Ba}$ compared to seawater (Gaillardet et al., 2003; Shaw et al., 1998). Finally, the temperature dependent partitioning of $\mathrm{Ba}$ between inorganic aragonite and fluid has been determined experimentally

Table 1

Coral $\mathrm{Ba} / \mathrm{Ca}$ environmental proxy studies.

\begin{tabular}{|c|c|c|c|c|c|}
\hline Reference & 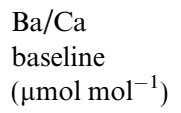 & 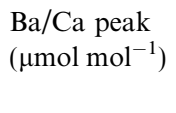 & Proxy & Species & Location \\
\hline Jupiter et al. (2008) & $\begin{array}{l}3.5 \\
4 \\
3\end{array}$ & $\begin{array}{l}7 \\
6 \\
8\end{array}$ & $\begin{array}{l}\text { River } \\
\text { River } \\
\text { River }\end{array}$ & $\begin{array}{l}\text { Porites } \\
\text { Porites } \\
\text { Porites }\end{array}$ & $\begin{array}{l}\text { Round Top island, Great Barrier Reef } \\
\text { Keswick Island, Great Barrier Reef } \\
\text { Scawfell Island, Great Barrier Reef }\end{array}$ \\
\hline Prouty et al. (2010) & $\begin{array}{l}3.4 \\
5.5 \\
2.8 \\
3\end{array}$ & $\begin{array}{l}8.0 \\
10.2 \\
21.6 \\
17.8\end{array}$ & $\begin{array}{l}\text { Sediment } \\
\text { Sediment } \\
\text { Sediment } \\
\text { Sediment }\end{array}$ & $\begin{array}{l}\text { P. lobata } \\
\text { P. lobata } \\
\text { P. lobata } \\
\text { P. lobata }\end{array}$ & $\begin{array}{l}\text { Kamalo, Molok'a Reef, Hawaii } \\
\text { One Ali'i, Molok'a Reef, Hawaii } \\
\text { Umpipa'a, Molok'a Reef, Hawaii } \\
\text { Pala'au, Molok'a Reef, Hawaii }\end{array}$ \\
\hline Wyndham et al. (2004) & $\begin{array}{l}4 \\
4\end{array}$ & $\begin{array}{l}15 \\
15\end{array}$ & $\begin{array}{l}\text { Unknown } \\
\text { Unknown }\end{array}$ & $\begin{array}{l}\text { Porites } \\
\text { Porites }\end{array}$ & $\begin{array}{l}\text { Havannah Island, Great Barrier Reef } \\
\text { Pandora Reef, Great Barrier Reef }\end{array}$ \\
\hline McCulloch et al. (2003) & 4 & 12 & River & Porites & $\begin{array}{l}\text { Havannah Island and Pandora Reef, Great } \\
\text { Barrier Reef }\end{array}$ \\
\hline Reuer et al. (2003) & 4.7 & 5.7 & Upwelling & $\begin{array}{l}\text { Montastrea } \\
\text { annularis }\end{array}$ & Isla Tortuga, Venezuela \\
\hline $\begin{array}{l}\text { Sinclair and McCulloch } \\
\text { (2004) }\end{array}$ & $\begin{array}{l}4 \\
4\end{array}$ & $\begin{array}{l}12 \\
17\end{array}$ & $\begin{array}{l}\text { River } \\
\text { River }\end{array}$ & $\begin{array}{l}\text { Porites } \\
\text { Porites }\end{array}$ & $\begin{array}{l}\text { King Reef, Great Barrier Reef } \\
\text { Pandora Reef, Great Barrier Reef }\end{array}$ \\
\hline Chen et al. (2011) & $\begin{array}{l}6 \\
6\end{array}$ & $\begin{array}{l}15 \\
15\end{array}$ & $\begin{array}{l}\text { Physiological } \\
\text { Physiological }\end{array}$ & $\begin{array}{l}\text { Porites } \\
\text { Porites }\end{array}$ & $\begin{array}{l}\text { Daya Bay, South China Sea } \\
\text { Daya Bay, South China Sea }\end{array}$ \\
\hline Fleitmann et al. (2007) & 4 & $\begin{array}{l}50 \\
9.5\end{array}$ & $\begin{array}{l}\text { River/ } \\
\text { sediment } \\
\text { River/ } \\
\text { sediment }\end{array}$ & $\begin{array}{l}\text { Porites } \\
\text { Porites }\end{array}$ & $\begin{array}{l}\text { Kenya } \\
\text { Kenya }\end{array}$ \\
\hline Sinclair (2005) & $\begin{array}{l}4 \\
4\end{array}$ & $\begin{array}{l}13 \\
12\end{array}$ & $\begin{array}{l}\text { Unknown } \\
\text { Unknown }\end{array}$ & $\begin{array}{l}\text { Porites } \\
\text { Porites }\end{array}$ & $\begin{array}{l}\text { Cow Island, Great Barrier Reef } \\
\text { Orpheus Island, Great Barrier Reef }\end{array}$ \\
\hline $\begin{array}{l}\text { Montaggioni et al. } \\
(2006)\end{array}$ & $\begin{array}{l}4.3 \\
1.3\end{array}$ & $\begin{array}{l}21 \\
5.2\end{array}$ & $\begin{array}{l}\text { Upwelling } \\
\text { River }\end{array}$ & $\begin{array}{l}\text { P. lobata } \\
\text { P. lobata }\end{array}$ & $\begin{array}{l}\text { Amedee Islet, New Caledonia } \\
\text { Vata Ricaudy Reef, New Caledonia }\end{array}$ \\
\hline Lea et al. (1989) & 4.1 & 5.1 & Upwelling & Pavona clavus & Galapagos Islands \\
\hline $\begin{array}{l}\text { Alibert and Kinsley } \\
(2008)\end{array}$ & 4 & 25 & Upwelling & Porites & New Ireland, Papua New Guinea \\
\hline $\begin{array}{l}\text { Carriquiry and Horta- } \\
\text { Puga (2010) }\end{array}$ & 7.5 & $\begin{array}{l}9.3 \\
9.3\end{array}$ & $\begin{array}{l}\text { River } \\
\text { River }\end{array}$ & $\begin{array}{l}\text { Montastraea } \\
\text { faveolata } \\
\text { M. Faveolata }\end{array}$ & $\begin{array}{l}\text { Anegada de Adentro Reef, Veracruz Reef } \\
\text { System, Gulf of Mexico } \\
\text { Isla Verde, Veracruz Reef System, Gulf of } \\
\text { Mexico }\end{array}$ \\
\hline $\begin{array}{l}\text { Horta-Puga and } \\
\text { Carriquiry (2012) }\end{array}$ & $\begin{array}{l}4.7 \\
4.3\end{array}$ & $\begin{array}{l}7.5 \\
5.6\end{array}$ & $\begin{array}{l}\text { Groundwater } \\
\text { Groundwater }\end{array}$ & $\begin{array}{l}\text { M. annularis } \\
\text { M. annularis }\end{array}$ & $\begin{array}{l}\text { Cancun, Mexico } \\
\text { Cancun, Mexico }\end{array}$ \\
\hline Fallon et al. (1999) & 3.9 & 5.1 & Upwelling & P. lobata & Shirigai Bay, Japan \\
\hline Moyer et al. (2012) & 3.3 & 4.8 & River & M. Faveolata & Fajardo Puerto Rico \\
\hline Tudhope et al. (1996) & $\begin{array}{l}5 \\
3\end{array}$ & $\begin{array}{l}15 \\
6\end{array}$ & $\begin{array}{l}\text { Upwelling } \\
\text { Upwelling }\end{array}$ & $\begin{array}{l}\text { Porites } \\
\text { Porites }\end{array}$ & $\begin{array}{l}\text { Marbat, Oman, Red Sea } \\
\text { Wadi Ayn, Oman, Red sea }\end{array}$ \\
\hline
\end{tabular}


(Dietzel et al., 2004; Gaetani and Cohen, 2006). Indeed, variability in coral $\mathrm{Ba} / \mathrm{Ca}$ ratios typically cannot be explained by temperature changes alone, indicating additional influences. However, several studies report coral $\mathrm{Ba} / \mathrm{Ca}$ ratios that did not vary in concert with a known driver. For example, Tudhope et al. (1996) and Sinclair (2005) reported elevated coral $\mathrm{Ba} / \mathrm{Ca}$ that did not correlate to known upwelling or river runoff sources. Such uncertainty highlights the need to better understand the origin of coral $\mathrm{Ba} / \mathrm{Ca}$ as an environmental proxy.

Coral $\mathrm{Ba} / \mathrm{Ca}$-based climate records are typically constructed by regressing coral $\mathrm{Ba} / \mathrm{Ca}$ against a measure of the parameter of interest (e.g. river discharge or water temperature or nutrients as a proxy for upwelling) with the underlying assumption that variability in the $\mathrm{Ba} / \mathrm{Ca}$ of the coral skeleton reflects changes in seawater chemistry caused by variability in the environmental driver (Table 1). In order for this assumption to be true, the following conditions have to be met: first, temperature driven changes in coral $\mathrm{Ba} / \mathrm{Ca}$ should be insignificant compared to the other driver of the $\mathrm{Ba} / \mathrm{Ca}$ signal, or can be adequately corrected for; second, seawater $\mathrm{Ba} / \mathrm{Ca}$ should increase in direct proportion to the proposed driver (i.e. terrestrial input, river flow, and groundwater discharge); and third, corals should incorporate the seawater $\mathrm{Ba} / \mathrm{Ca}$ signal in a predictable fashion.

To gain a mechanistic understanding of the $\mathrm{Ba} / \mathrm{Ca}$ coral proxy and test the three conditions listed above, we grew Favia fragum coral polyps in seawater amended with $\mathrm{Ba}$ at three different concentrations and three different temperatures to quantify solid-solution Ba partitioning as a function of temperature, calcification rate, aragonite saturation state, and seawater Ba concentration.

\section{METHODS}

\subsection{Experimental conditions}

The coral culture experiments were performed at the Bermuda Institute of Ocean Sciences (BIOS) in July 2011. Nine aquaria $(20 \mathrm{~L})$ were established in three different temperature controlled $\left(\sim 27.7,24.6\right.$ and $\left.22.5^{\circ} \mathrm{C}\right)$ and $\mathrm{Ba}-$ amended $\left(73,230\right.$ and $\left.450 \mathrm{nmol} \mathrm{kg}{ }^{-1}\right)$ baths such that each tank had a different combination of temperature and $\mathrm{Ba}$ concentration (Table 2). These Ba concentrations are well below the saturation state of witherite $\left(\mathrm{BaCO}_{3}\right)$ (log equilibrium constant $=-8.57$ (Busenberg and Plummer, 1986), experiment $\log$ solubility product $=-10.0$ to -10.9 ). Sea water was supplied from the lagoon adjacent to BIOS through a seawater intake and had an ambient temperature of $27^{\circ} \mathrm{C}$ and $\mathrm{Ba}$ concentration of $44 \mathrm{nmol} \mathrm{kg}{ }^{-1}$. Temperature was monitored in all but one of the tanks with Onset ${ }^{\mathrm{TM}}$ HOBO water temperature loggers and the three tanks at each temperature treatment shared a water bath. Ambient $\mathrm{CO}_{2}$ conditions were maintained by directly bubbling air through micropore bubble 'wands' attached at the base of each aquarium thereby maintaining a stable aragonite saturation state; this also served to keep the tanks well mixed. The tanks were drained and refilled with filtered seawater $(5 \mu \mathrm{m})$ at the beginning of the experiment and then on days
5 and 11 to prevent the buildup of nutrients during the 14day experiment. Once the tanks were filled, they were amended with a dissolved $\mathrm{Ba}$ standard (a high purity $\mathrm{BaCO}_{3}$ dissolved in $0.11 \%$ nitric acid, Fluka ${ }^{\circledR}$ Analytical). Samples for salinity, trace element content, total alkalinity (TA), and dissolved inorganic carbon (DIC) were collected at the beginning and end of the experiment, as well as prior to each water change and after the element addition had equilibrated in the tank for one hour (a total of 8 measurements of water chemistry in each tank during the course of the experiment). Some evaporation was observed despite plastic covering on the aquaria, which likely explains the range in salinities and water chemical properties observed among different tanks over time (Table 2 and Supplemental Table 1).

\subsection{Coral culture}

Mature adult $F$. fragum colonies were collected from nearby reefs 3 to 5 days prior to the July spawn (Goodbody-Gringley and de Putron, 2009). They were kept in outdoor flow-through aquaria during the day and isolated at night. Zooxanthellate larvae were collected each morning, and then added to plastic containers with mesh tops containing ceramic tiles (de Putron et al., 2011). These tiles were preconditioned for larval recruitment by placing them on the nearby reef for several months prior to use. During this time, encrusting coralline algae (hereafter CCA) and other algal growth was established on the tiles. Some CCA and algal growth was removed from the tile prior to use in the experiment, thus CCA growth occurred during pre-conditioning on the reef as well as in controlled aquaria conditions. The larvae were then allowed to settle on these tiles in aquaria established at experimental conditions for $48 \mathrm{~h}$ to encourage coral planulae to attach to the tiles and metamorphose into polyps, at which point calcification of the coral skeleton begins. At this point, the tiles were removed from the mesh-topped containers and placed directly in the aquaria. Each day, light levels were maintained for $12 \mathrm{~h}$ at $215 \pm 59 \mu \mathrm{mol}$ quanta $\mathrm{m}^{-2} \mathrm{~s}^{-1}$ ( \pm indicates one standard deviation throughout). The polyps were allowed to grow for 14 days, after which the polyps were removed from the aquaria, rinsed with a $5 \%$ bleach solution to remove organic material, subsequently rinsed with deionized water, and dried (Drenkard et al., 2013).

\subsection{Analytical methods}

Tank salinity was measured at BIOS with an Autosal salinometer. The alkalinity and dissolved inorganic carbon samples were poisoned with mercuric chloride immediately after collection and analyzed using a Marianda VINDTA$3 \mathrm{C}$ analysis system at Woods Hole Oceanographic Institution. Total alkalinity was determined by non-linear curve fitting of data obtained by open-cell titrations and DIC concentrations were determined by coulometric analysis. The $p \mathrm{CO}_{2}$ and aragonite saturation state were calculated from discrete tank temperature, salinity, TA, and DIC samples using the CO2SYS program (Lewis and Wallace, 1998; 
Table 2

Aquaria experimental conditions, dissolved $\mathrm{Ba}$, coral precipitation rate, solid $\mathrm{Ba} / \mathrm{Ca}$ and $\mathrm{Sr} / \mathrm{Ca}$ and $\mathrm{K}_{\mathrm{Ba}}$.

\begin{tabular}{|c|c|c|c|c|c|c|c|c|c|c|c|}
\hline Tank\# & Salinity \pm SD & $\begin{array}{l}\text { Temperature } \\
\left({ }^{\circ} \mathrm{C} \pm \mathrm{SD}\right)\end{array}$ & $\begin{array}{l}\mathrm{CO}_{2} \\
(\mathrm{ppmv} \pm \mathrm{SD})\end{array}$ & $\Omega_{\mathrm{AR}}( \pm \mathrm{SD})$ & $\begin{array}{l}{[\mathrm{Ba}]} \\
\left(\mathrm{nmol} \mathrm{kg}{ }^{-1}\right. \\
\pm \mathrm{SD})\end{array}$ & 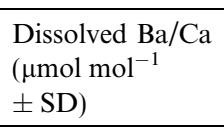 & $\begin{array}{l}\text { Calcification rate } \\
\left(\mathrm{mg} \mathrm{d}^{-1} \pm \mathrm{SD}\right)\end{array}$ & 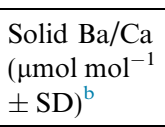 & 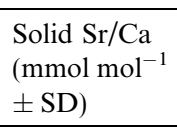 & $\mathrm{K}_{\mathrm{Ba}}{ }^{\mathrm{b}}$ & $\begin{array}{l}\text { Individuals/ } \\
\text { Measurements }\end{array}$ \\
\hline 1: coral & $34.7 \pm 1.1$ & $27.7 \pm 0.9$ & $320 \pm 50$ & $3.2 \pm 0.3$ & $79 \pm 23$ & $7.5 \pm 2.0$ & $6.2 \pm 4.2$ & $12.1 \pm 1.6$ & $8.2 \pm 0.6$ & $1.62 \pm 0.21$ & $43 / 24$ \\
\hline 2: coral & $34.9 \pm 1.1$ & $27.8 \pm 1.0$ & $320 \pm 30$ & $3.3 \pm 0.2$ & $223 \pm 26$ & $22 \pm 2.4$ & $4.2 \pm 3.2$ & $37.1 \pm 5.7$ & $7.8 \pm 0.5$ & $1.69 \pm 0.26$ & $37 / 21$ \\
\hline 3: coral & $35.2 \pm 0.5$ & $27.7 \pm 0.9$ & $350 \pm 80$ & $2.9 \pm 0.5$ & $463 \pm 24$ & $44 \pm 2.4$ & $7.0 \pm 3.4$ & $77.2 \pm 6.1$ & $8.2 \pm 0.5$ & $1.63 \pm 0.11$ & $36 / 22$ \\
\hline 4: coral & $35.3 \pm 0.6$ & $24.7 \pm 0.9$ & $410 \pm 30$ & $3.0 \pm 0.1$ & $73 \pm 12$ & $7.0 \pm 1.1$ & $5.0 \pm 4.3$ & $12.4 \pm 1.2$ & $8.0 \pm 0.5$ & $1.76 \pm 0.18$ & $38 / 20$ \\
\hline 5: coral & $35.3 \pm 0.4$ & $24.6 \pm 0.6$ & $380 \pm 60$ & $3.1 \pm 0.4$ & $236 \pm 22$ & $23 \pm 2.1$ & $5.2 \pm 4.5$ & $36.5 \pm 6.5$ & $8.3 \pm 0.7$ & $1.62 \pm 0.29$ & $33 / 18$ \\
\hline 6: coral & $35.3 \pm 0.3$ & $24.5 \pm 0.5$ & $520 \pm 100$ & $2.4 \pm 0.4$ & $439 \pm 9$ & $42 \pm 1.0$ & $3.1 \pm 1.7$ & $77.1 \pm 6.2$ & $8.4 \pm 0.5$ & $1.71 \pm 0.13$ & $48 / 15$ \\
\hline 7: coral & $35.4 \pm 0.5$ & $(22.5 \pm 1.1)^{\mathrm{a}}$ & $490 \pm 30$ & $3.0 \pm 0.0$ & $72 \pm 13$ & $6.8 \pm 1.1$ & $2.6 \pm 1.7$ & $14.2 \pm 2.7$ & $7.7 \pm 0.6$ & $2.09 \pm 0.40$ & $47 / 14$ \\
\hline 8: coral & $35.3 \pm 0.5$ & $22.4 \pm 1.1$ & $550 \pm 20$ & $2.7 \pm 0.1$ & $220 \pm 38$ & $21 \pm 3.5$ & $1.9 \pm 1.0$ & $42.6 \pm 3.1$ & $7.7 \pm 0.6$ & $1.87 \pm 0.11$ & $26 / 10$ \\
\hline 9: coral & $35.3 \pm 0.3$ & $22.6 \pm 1.1$ & $700 \pm 30$ & $2.1 \pm 0.1$ & $440 \pm 11$ & $43 \pm 1.8$ & $1.0 \pm 0.6$ & $77.2 \pm 2.9$ & $8.4 \pm 0.4$ & $1.78 \pm 0.07$ & $23 / 4$ \\
\hline $\begin{array}{l}1,4,7: \\
\text { CCA }\end{array}$ & $35.1 \pm 0.8$ & $\begin{array}{l}\text { Includes }^{\mathrm{d}} \text { all } \\
\mathrm{T} \text { treatments, } \\
22.4-27.8\end{array}$ & $410 \pm 80^{\mathrm{d}}$ & $3.1 \pm 0.2$ & $75 \pm 17$ & $7.1 \pm 1.5$ & $\mathrm{nc}$ & $8.8 \pm 0.8$ & $3.5 \pm 1.0$ & $\mathrm{nc}$ & $3 / 3$ \\
\hline $\begin{array}{l}2,5,8: \\
\text { CCA }\end{array}$ & $35.2 \pm 0.7$ & $\begin{array}{l}\text { Includes }^{\mathrm{d}} \text { all } \\
\mathrm{T} \text { treatments, } \\
22.4-27.8\end{array}$ & $415 \pm 110^{\mathrm{d}}$ & $3.0 \pm 0.3$ & $225 \pm 28$ & $22 \pm 2.6$ & $\mathrm{nc}$ & $13.4 \pm 1.9$ & $3.4 \pm 0.7$ & $\mathrm{nc}$ & $3 / 3$ \\
\hline $\begin{array}{l}3,6,9: \\
\text { CCA }\end{array}$ & $35.3 \pm 0.4$ & $\begin{array}{l}\text { Includes }^{\mathrm{d}} \text { all } \\
\mathrm{T} \text { treatments, } \\
22.4-27.8\end{array}$ & $525 \pm 170^{\mathrm{d}}$ & $2.5 \pm 0.5$ & $447 \pm 27$ & $43 \pm 2.7$ & $\mathrm{nc}$ & $35.0 \pm 9.2$ & $5.0 \pm 1.1$ & $\mathrm{nc}$ & $2 / 2$ \\
\hline
\end{tabular}

${ }^{\text {a }}$ Temperature was not measured in tank 7, so temperature is the average of tanks 8 and 9, which shared the same temperature-controlled water bath.

${ }^{\mathrm{b}} \mathrm{Coral} \mathrm{Ba} / \mathrm{Ca}$ and $\mathrm{K}_{\mathrm{Ba}}$ were calculated after correction for CCA contamination.

${ }^{c}$ Groups of individuals were combined for elemental analysis on samples of $\geq 70 \mu \mathrm{g}$. $\mathrm{K}_{\mathrm{Ba}}$ was calculated from these combined samples. nc: not calculated for encrusting coralline algae (CCA).

${ }^{\mathrm{d}}$ CCA physical parameters are averaged over tanks: 1, 4, 7 (low Ba treatment), 2, 5, 8 (medium Ba treatment) and 3, 6, 9 (high Ba treatment). 
Pelletier et al., 2007) utilizing the constants of Mehrbach et al. (1973) as refit by Dickson and Millero (1987).

Each corallite, the coral skeleton, was examined under a microscope, removed from the ceramic tile and weighed on a microbalance (Cohen and Holcomb, 2009). This weight was used to calculate calcification rate over the 14-day experiment. Efforts were made to remove only the corallite, however some material from the heavily encrusted tiles adhered to the corallites, as evidenced by low $\mathrm{Sr} / \mathrm{Ca}$ ratios (see discussion in Section 3.1 below). Several samples of CCA were also removed and analyzed in the same manner as coral samples. Elemental analysis was conducted on individual skeletons that weighed at least $70 \mu \mathrm{g}$, otherwise multiple individuals from the same tile were grouped together for analysis. Skeletal material was dissolved in 5\% Optima nitric acid and analyzed via inductively coupled plasma mass spectrometry (ICP-MS) on a Finnigan Element II at the Woods Hole Oceanographic Institution ICP-MS Facility. Counts of ${ }^{48} \mathrm{Ca},{ }^{88} \mathrm{Sr}$ and ${ }^{138} \mathrm{Ba}$ were made in low-resolution mode with 45 scans per sample and a 3 -minute wash in 5\% nitric acid between samples. Sample counts were blank corrected with a 5\% nitric acid solution. $\mathrm{Ba} / \mathrm{Ca}$ and $\mathrm{Sr} / \mathrm{Ca}$ elemental standards were gravimetrically prepared and used to monitor instrument drift. Three carbonate reference materials were analyzed, including two fish otolith standards (FEBS-1, $\mathrm{Ba} / \mathrm{Ca}=4.2 \mu \mathrm{mol} \quad \mathrm{mol}^{-1}, \quad \mathrm{Sr} / \mathrm{Ca}=2.5 \mathrm{mmol} \mathrm{mol}^{-1}$ National Research Council Canada, and one detailed in Yoshinaga et al. (2000), Ba/Ca $=2.2 \mu \mathrm{mol} \mathrm{mol}^{-1}, \mathrm{Sr} /$ $\left.\mathrm{Ca}=2.8 \mathrm{mmol} \mathrm{mol}^{-1}\right)$ and the $\mathrm{JCp}-1$ coral reference standard $\left(\mathrm{Ba} / \mathrm{Ca}=7.5 \mu \mathrm{mol} \mathrm{mol}^{-1}, \mathrm{Sr} / \mathrm{Ca}=8.7 \mathrm{mmol} \mathrm{mol}^{-1}\right.$, Okai et al. (2002)). Based on repeated standard measurements analytical uncertainty for $\mathrm{Ba} / \mathrm{Ca}$ was $1 \mu \mathrm{mol} \mathrm{mol}^{-1}$ and for $\mathrm{Sr} / \mathrm{Ca}, 0.5 \mathrm{mmol} \mathrm{mol}^{-1}$.

Dissolved $\mathrm{Ba}$ in aliquots (filtered at $0.22 \mu \mathrm{m}$ ) from each tank in the coral culture experiment was analyzed by isotope dilution mass spectrometry (Fassett and Paulsen, 1989). Samples were diluted 25 times with 5\% Optima nitric acid, spiked with ${ }^{135} \mathrm{Ba}$ and analyzed via ICP-MS for masses ${ }^{135} \mathrm{Ba}$ and ${ }^{138} \mathrm{Ba}$ in low-resolution mode with 45 scans per sample and a 3-minute rinse in 5\% nitric acid. Sample counts were corrected for blanks measured in 5\% nitric acid. Ca concentrations were determined with a Dionex ion chromatograph referenced to the IAPSO standard $\left(10.5 \pm 0.1 \mathrm{mmol} \mathrm{kg}^{-1}, \mathrm{n}=20\right)$. To quantify accuracy, Ba was measured in the SLRS-4 dissolved reference material $\left(89.3 \pm 1.8 \mathrm{nmol} \mathrm{kg}^{-1} \quad\right.$ (measured) compared to $88.8 \mathrm{nmol} \mathrm{kg}^{-1}$ (reference), $\mathrm{n}=10$ ). Additional reference waters without certified $\mathrm{Ba}$ concentrations were measured to determine analytical precision and uncertainty at higher and lower $\mathrm{Ba}$ concentrations: NASS-5: $45 \pm 0.5$ and SLEW-3: $179 \pm 2, \mathrm{n}=10$ ); analytical uncertainty was $2 \mathrm{nmol} \mathrm{kg}^{-1}$ based on these replicate analyses since sample Ba concentrations were greater than $70 \mathrm{nmol} \mathrm{kg}{ }^{-1}$.

\section{RESULTS}

\subsection{Coral barium incorporation experiments}

Conditions within the individual tanks are shown in Table 2 and Supplemental Table 1. Salinity in all tanks was $\sim 35$, with a standard deviation of $3 \%$. The three temperature conditions $\left(27.7,24.6\right.$ and $\left.22.5^{\circ} \mathrm{C}\right)$ experienced a standard deviation of $1.1^{\circ} \mathrm{C}$ over the course of the 14-day experiment. The $\mathrm{CO}_{2}$ content and resulting aragonite saturation state is dependent on the water temperature, thus tanks at lower temperatures had slightly higher $\mathrm{CO}_{2}$ levels and lower saturation states. This was particularly evident in Tank 9, the low temperature, high Ba tank (Table 2). Coral polyps in this tank had the lowest calcification rates (Table 2). However, in general, most tanks had a saturation state of approximately 3 . The three different dissolved $\mathrm{Ba}$ concentrations $\left(\sim 73,230\right.$ and $\left.450 \mathrm{nmol} \mathrm{kg}{ }^{-1}\right)$ were maintained in the aquaria for the length of the experiment with a standard deviation of $1-2.5 \mathrm{nmol} \mathrm{kg}{ }^{-1}$ (Table 2, Supplementary Table 1). The resulting water $\mathrm{Ba} / \mathrm{Ca}$ were 6.8 $7.5,21-23$ and $42-44 \mu \mathrm{mol} \mathrm{mol}^{-1}$ with a standard deviation of $1-3.5 \mu \mathrm{mol} \mathrm{mol}^{-1}$ (Table 2).

Coral polyps grown in seawater amended with $\mathrm{Ba}$ incorporated this signal in their skeletal material, demonstrating a direct response to increased seawater $\mathrm{Ba} / \mathrm{Ca}$ (individuals $\mathrm{n}=325$, element ratio measurements $\mathrm{n}=164$ due to analysis of some grouped individuals). However, low $\mathrm{Sr} / \mathrm{Ca}$ values and a linear trend between $\mathrm{Sr} / \mathrm{Ca}$ and $\mathrm{Ba} / \mathrm{Ca}$ suggested that calcite from encrusting coralline algae was included in samples with the coral aragonite (Fig. 1a). Samples of CCA material with no coral skeleton present had a $\mathrm{Sr} / \mathrm{Ca}$ ratio of $3.5 \pm 1.0,3.4 \pm 0.7$ and $5 \pm 1.1 \mathrm{mmol} \mathrm{mol}^{-1}$ and $\mathrm{Ba} / \mathrm{Ca}$ ratios of $8.8 \pm 1.8,13.4 \pm 1.9$ and $35 \pm 9.2 \mu \mathrm{mol} \mathrm{mol}^{-1}$ for the $\sim 73,230$ and $450 \mathrm{nmol} \mathrm{kg} \mathrm{kg}^{-1}$ Ba treatment levels, respectively (Table 2). To correct for inclusion of CCA material, which would lower $\mathrm{Ba} / \mathrm{Ca}$ ratios relative to pure aragonite (see mixing line in Fig. 1a), we calculated twoend member mixing between the contaminating CCA phase and aragonite. In this approach, we use $\mathrm{Sr} / \mathrm{Ca}$ ratios to estimate the fraction of CCA in each sample according to:

$f_{\mathrm{C}}=\frac{\mathrm{Sr} / \mathrm{Ca}_{\mathrm{M}}-\mathrm{Sr} / \mathrm{Ca}_{\mathrm{A}}}{\mathrm{Sr} / \mathrm{Ca}_{\mathrm{C}}-\mathrm{Sr} / \mathrm{Ca}_{\mathrm{A}}}$

where $\mathrm{Sr} / \mathrm{Ca}_{\mathrm{M}}, \mathrm{Sr} / \mathrm{Ca}_{\mathrm{A}}$, and $\mathrm{Sr} / \mathrm{Ca}_{\mathrm{C}}$ are the measured corallite, aragonite end member and $\mathrm{CCA}$ ratios respectively. The aragonite end member was estimated from the temperature dependence of aragonite $\mathrm{Sr} / \mathrm{Ca}$ ratios:

$\mathrm{Sr} / \mathrm{Ca}=10.781-0.0597 T \quad$ (Porites, [Felis etal., 2004])

$\mathrm{Sr} / \mathrm{Ca}=10.73-0.0657 T \quad$ (Porites, [Correge etal., 2000])

$\mathrm{Sr} / \mathrm{Ca}=10.184-0.00408 T \quad$ (Favia, [Seo etal., 2013])

These three $\mathrm{Sr} / \mathrm{Ca}$ temperature relationships are quite different; the two Porites relationships used here were chosen since they predict coral aragonite $\mathrm{Sr} / \mathrm{Ca}$ ratios that vary by $0.2 \mathrm{mmol} \mathrm{mol}^{-1}$ over the temperature range of these experiments, while the Seo et al. (2013) relationship is exclusively for the species used in these experiments (Favia). When the fraction of material contributed by CCA is calculated from Eq. (1) using aragonite $\mathrm{Sr} / \mathrm{Ca}$ end member values from either Eqs. (2), (3) or (4), the difference was 

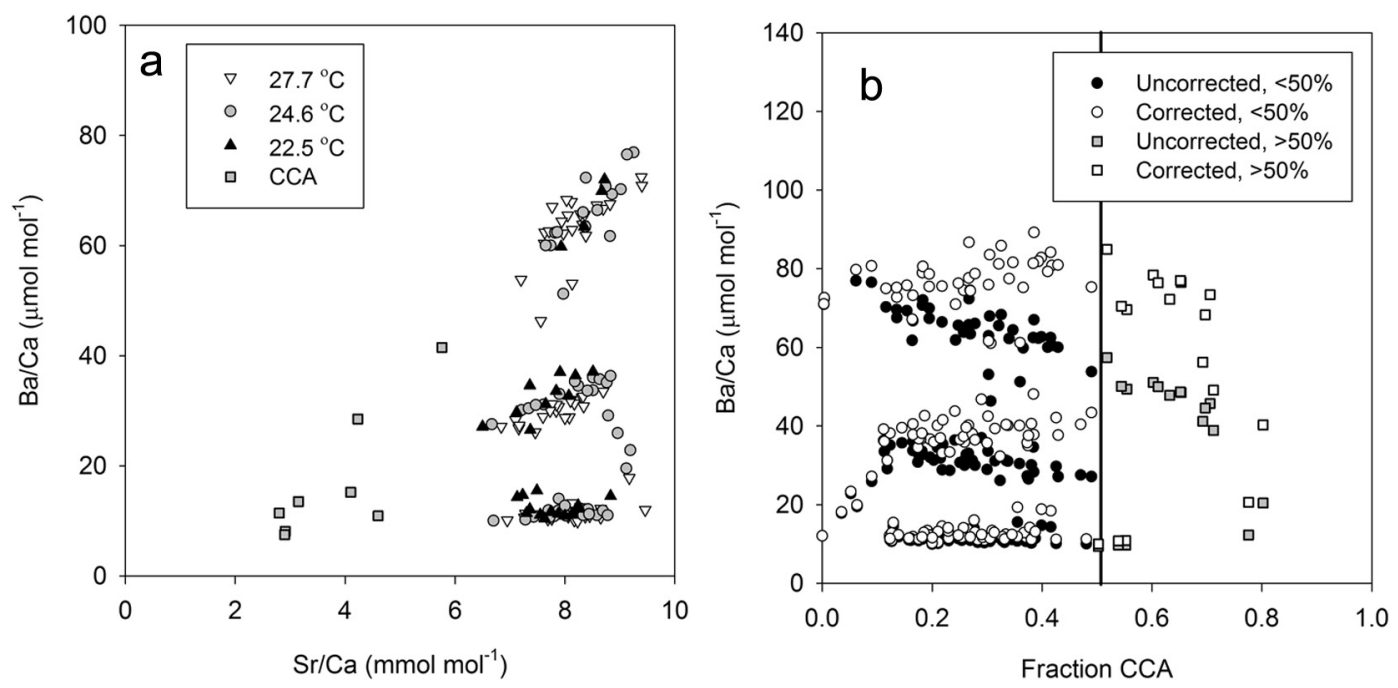

Fig. 1. (a) There is a linear relationship between $\mathrm{Sr} / \mathrm{Ca}$ and $\mathrm{Ba} / \mathrm{Ca}$ for the Favia fragum corallites that lies outside values anticipated for pure aragonite phases, suggesting mixing of a encrusting coralline algae (CCA) end member (gray squares) with aragonite. (b) Ba/Ca for uncorrected (solid symbols) and corrected (empty symbols) versus fraction CCA contribution to the sample based on two end member mixing with $\mathrm{Sr} / \mathrm{Ca}$. Samples with a CCA contribution $>50 \mathrm{wt} \%$ (squares) were excluded from analysis.

small $(3 \pm 1 \%)$. In the end, we chose to include all three relationships in the uncertainty analysis to produce the most reasonable uncertainty for the fraction CCA and resulting corrected coral $\mathrm{Ba} / \mathrm{Ca}$ (see below). Uncertainty associated with corrections for CCA contamination was constrained with Monte Carlo simulations ( $10^{5}$ iterations) using the following uncertainties (Table 2): (1) CCA Sr/ $\mathrm{Ca}$ measurement average and standard deviation for each treatment, (2) analytical $\mathrm{Sr} / \mathrm{Ca}$ measurement uncertainty, (3) tank temperature average and standard deviation and (4) the average coral $\mathrm{Sr} / \mathrm{Ca}$ for coral aragonite calculated according to Eqs. (2), (3) and (4). The simulations suggest that on average CCA contributed $30 \pm 16 \mathrm{wt} \%$ (Fig. 1b). Samples with greater than $50 \mathrm{wt} \%$ CCA contribution (18 of the 164 samples, Fig. 1b and Supplemental Table 2) had very high corrected $\mathrm{Ba} / \mathrm{Ca}$ and were excluded from all further analysis. Excluding those samples resulted an average CCA contribution by weight of $26 \pm 11 \%$.

The same two end member mixing relationship was used to calculate the $\mathrm{Ba} / \mathrm{Ca}$ ratio of the coral aragonite:

$\mathrm{Ba} / \mathrm{Ca}_{\mathrm{A}}=\frac{\mathrm{Ba} / \mathrm{Ca}_{\mathrm{M}}-f_{\mathrm{C}} \mathrm{Ba} / \mathrm{Ca}_{\mathrm{C}}}{1-f_{\mathrm{C}}}$

where $\mathrm{Ba} / \mathrm{Ca}_{\mathrm{M}}$ is the measured ratio of the mixed coral and CCA sample, and $\mathrm{Ba} / \mathrm{Ca}_{\mathrm{C}}$ was $8.8 \pm 1.8,13.4 \pm 1.9$ and 35 $\pm 9.2 \mu \mathrm{mol} \mathrm{mol}^{-1}$ for the three Ba treatment levels. This correction assumes that CCA and aragonite have the same calcium concentration, which requires that the CCA endmember is some form of $\mathrm{CaCO}_{3}$. The average increase from measured $\mathrm{Ba} / \mathrm{Ca}$ to final aragonite values was 1.0 $\pm 0.8 \mu \mathrm{mol} \mathrm{mol}^{-1} \quad(9 \pm 6 \%), \quad 6.7 \pm 3.6 \mu \mathrm{mol} \mathrm{mol}^{-1}$ $\pm 12 \%$, and $11.9 \pm 6.2 \mu \mathrm{mol} \mathrm{mol}^{-1}(19 \pm 10 \%)$ for low, medium and high Ba treatments respectively (Fig. 1b). Once again, the temperature dependence of the $\mathrm{Sr} / \mathrm{Ca}$ ratio did not have a large impact on the resulting $\mathrm{Ba} / \mathrm{Ca}(1.0$ $\pm 0.9 \mu \mathrm{mol} \mathrm{mol}^{-1}$ difference between Eq. (3) and (4) for all 148 samples). We used Monte Carlo simulations to determine the uncertainty in corrected coral $\mathrm{Ba} / \mathrm{Ca}$, as discussed above, including these additional sources of uncertainty: (1) CCA $\mathrm{Ba} / \mathrm{Ca}$ measurement average and standard deviation for each treatment and (2) analytical $\mathrm{Ba} / \mathrm{Ca}$ measurement uncertainty. Corrected coral $\mathrm{Ba} / \mathrm{Ca}$ averaged $12.7 \pm 2.0,38.0 \pm 6.0$ and $77.2 \pm 5.8 \mu \mathrm{mol} \mathrm{mol}^{-1}$ at the three dissolved Ba concentrations (Fig. 2). While this correction is important, it does not change the conclusion that corals incorporate Ba linearly over this seawater $\mathrm{Ba}$ range.

The corallite calcification rate exhibited a temperature dependence, with higher calcification rates observed at higher temperatures $(n=325$, Fig. 3a). Inclusion of CCA material attached to the coral skeleton will result in calcification rates that are too large, so the same correction was done as above to remove the contribution of this material prior to calculating calcification rates. Since the correction could only be done for samples with measured $\mathrm{Sr} / \mathrm{Ca}$ ratios, when multiple individuals were grouped for a single analysis, the weighted calcification rate of that composite sample was corrected for CCA inclusion. We exclude samples with $>50 \mathrm{wt} \%$ CCA. All further discussion and analysis is based on these samples $(n=148$, Fig. $2 b-d)$. In addition to the diminished metabolic response at lower temperatures, these tanks also had a lower saturation state since $\mathrm{CO}_{2}$ is more soluble in water at 22.5 versus $27.7^{\circ} \mathrm{C}$. Calcification is inhibited at lower saturation states. The range in calcification rates for individual polyps was quite large, with the majority of specimens in the warm tanks $\left(27.7^{\circ} \mathrm{C}\right)$ having calcification rates between 4.2 and $7.0 \mathrm{mg} \mathrm{CaCO}_{3} \mathrm{~d}^{-1}$, while rates in the cool tanks $\left(22.5^{\circ} \mathrm{C}\right)$ fell between 1.0 and $2.6 \mathrm{mg} \mathrm{d}^{-1}$ (Fig. 3 and Table 2). The lowest calcification rates were also coincident with the lowest saturation states, particularly for tanks 9,8 and 6 , although there was no statistical difference (two-way factorial ANOVA test, $p>0.1)$ between saturation states at the different treatments. 

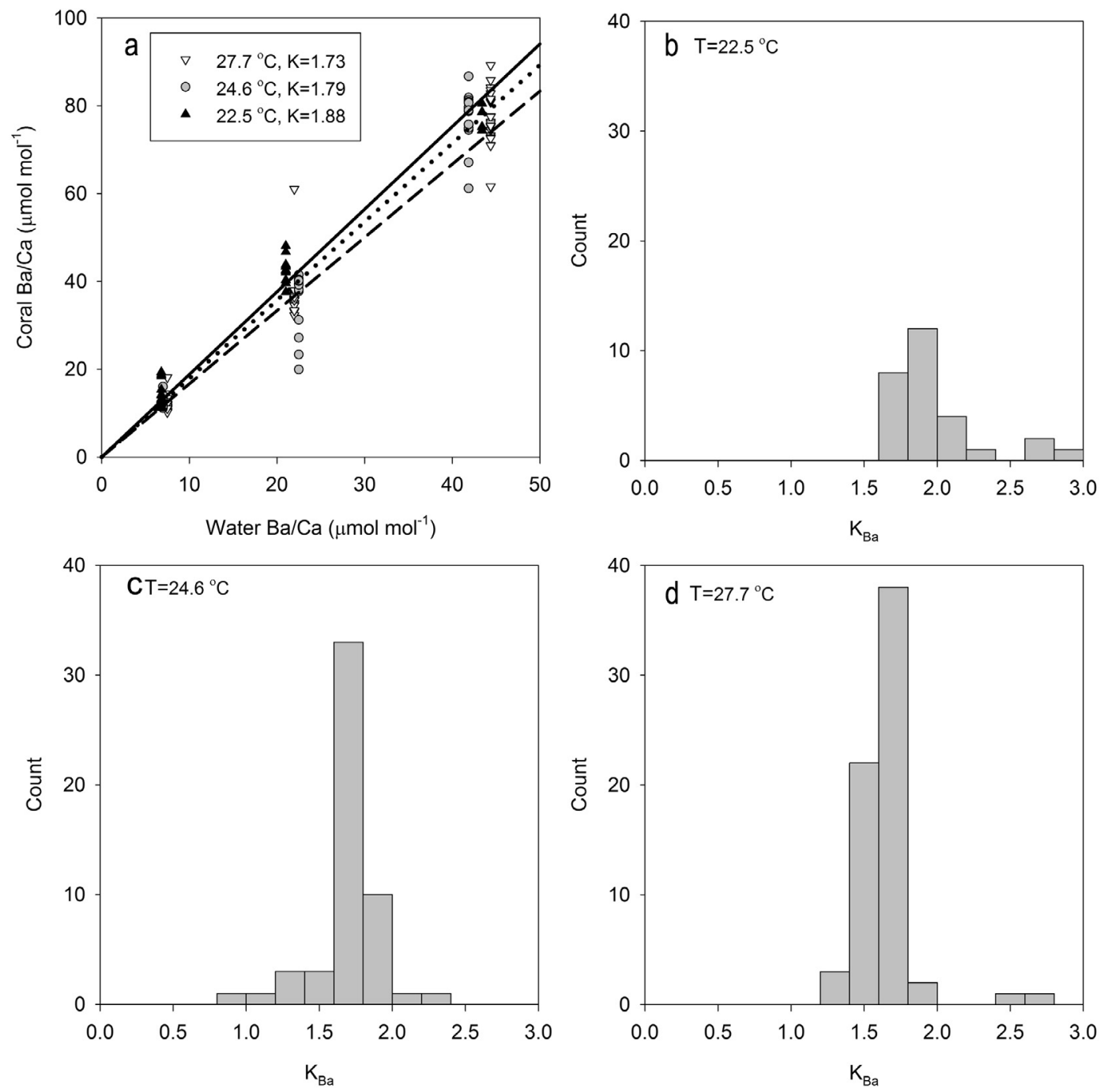

Fig. 2. (a) Coral Ba/Ca versus water $\mathrm{Ba} / \mathrm{Ca}$ for Favia fragum polyps grown in barium amended aquaria at three different temperatures. Bestfit lines are solid $\left(T=22.5^{\circ} \mathrm{C}\right)$, dotted $\left(T=24.6^{\circ} \mathrm{C}\right)$ and dashed $\left(T=27.7^{\circ} \mathrm{C}\right)$. These lines were fit through the origin and the slopes yield the experiment distribution coefficient, $\mathrm{K}$. Histogram of individual distribution coefficients for (b) $T=22.5^{\circ} \mathrm{C}$, (c) $T=24.6^{\circ} \mathrm{C}$ and (d) $T=27.7^{\circ}$ C, 11 bins for each temperature treatment.

\section{DISCUSSION}

\subsection{Coral Ba uptake}

The distribution coefficient describes the partitioning of Ba between solid aragonite and dissolved phases according to:

$$
\mathrm{K}_{\mathrm{Ba}}=\frac{\mathrm{Ba} / \mathrm{Ca}_{\text {argonite }}}{\mathrm{Ba} / \mathrm{Ca}_{\text {dissolved }}}
$$

The distribution coefficient must be constrained to quantitatively use coral $\mathrm{Ba} / \mathrm{Ca}$ as an environmental paleo proxy of ocean water chemistry. Experimental results indicate the corals incorporate $\mathrm{Ba}$ in direct proportion to the seawater dissolved $\mathrm{Ba}$ across a large concentration range (72-463 nmol kg-1). To our knowledge, this is the first time the concentration response of $\mathrm{Ba}$ uptake into coral aragonite has been demonstrated experimentally. Our results are consistent with those observed for other marine species (calcite foraminifera, Lea and Spero, 1992; and aragonitic fish otoliths, Bath et al., 2000; Elsdon and Gillanders, 2003). However, there is large variability in individual $\mathrm{Ba}$ uptake efficiency resulting in variable distribution coefficients (Figs. 2 and 4). Below we consider the potential impact of temperature, calcification rate, and aragonite saturation state on this inter-specimen variability.

\subsection{Coral Ba/Ca distribution coefficient}

\subsubsection{Temperature dependence of $K_{B a}$}

Experiments with inorganic aragonite over large temperature ranges $\left(10-75^{\circ} \mathrm{C}\right)$ show that $\mathrm{K}_{\mathrm{Ba}}$ is inversely related to temperature (Dietzel et al., 2004; Gaetani and Cohen, 2006), such that aragonite precipitated at a lower temperature will have a higher $\mathrm{Ba} / \mathrm{Ca}$ (Fig. 4a). There is a large range in skeletal $\mathrm{Ba} / \mathrm{Ca}$, as discussed above. To evaluate 

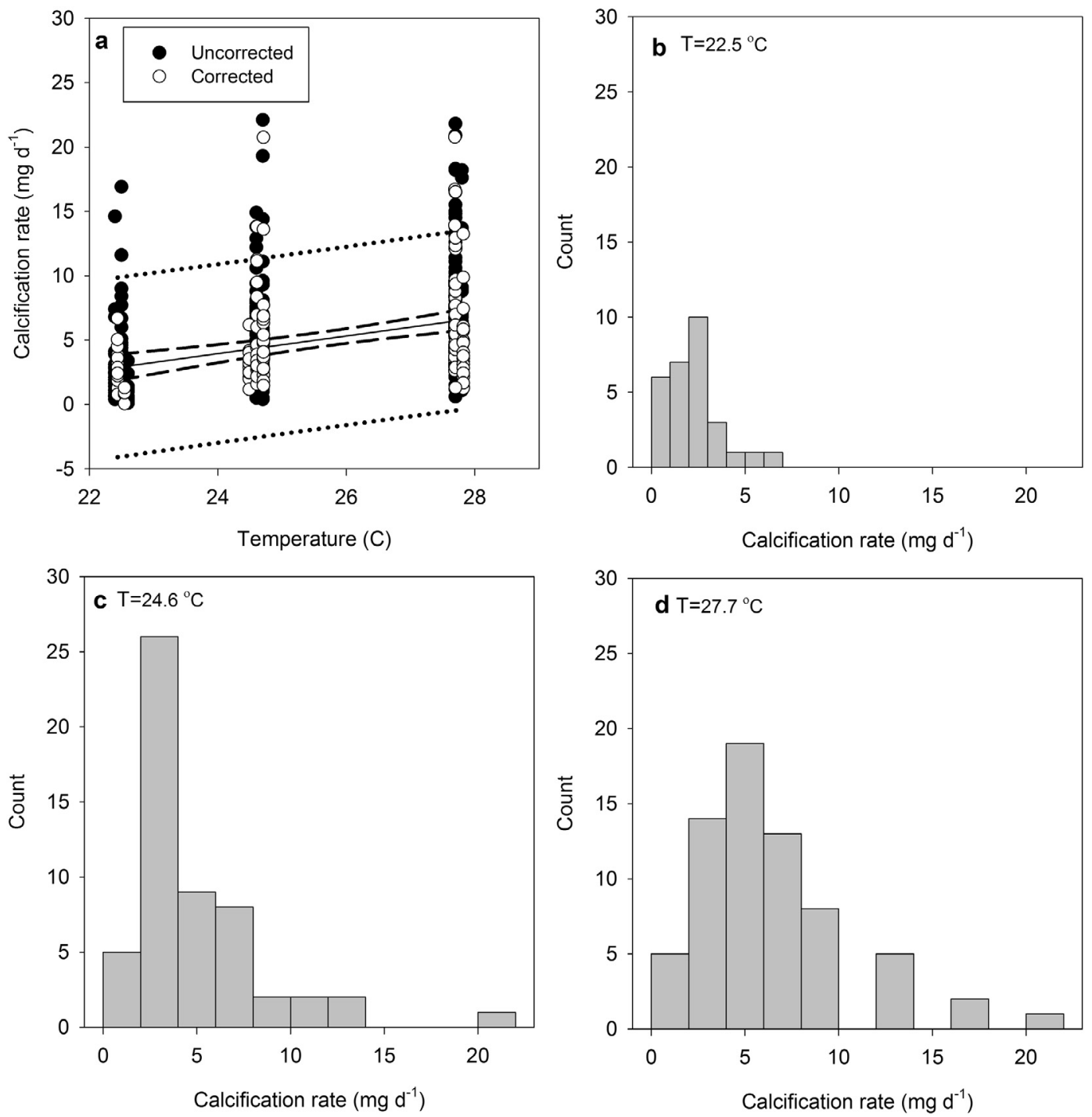

Fig. 3. (a) Coral calcification rate for uncorrected (solid) and CCA corrected (empty) versus temperature. Data at each temperature includes polyps from each of the three different $\mathrm{Ba}$ treatments. The best-fit line (solid) is shown for the relationship: coral calcification rate $=0.68 \times$ temperature $-12.29\left(T\right.$ in $\left.{ }^{\circ} \mathrm{C}, r^{2}=0.14, p<0.0001\right)$; dashed lines indicate the $95 \%$ confidence interval, while dotted line represents $95 \%$ prediction interval. Histograms of corrected calcification rate for each temperature treatment are shown in (b) $T=22.5^{\circ} \mathrm{C}$, (c) $T=24.6^{\circ} \mathrm{C}$ and (d) $T=27.7^{\circ} \mathrm{C}$. Precipitation rates from each treatment were grouped into an equal number of bins (11) in the histograms, corresponding to different bin ranges for each temperature.

the influence of temperature on Ba partitioning, the distribution coefficient at each experimental temperature was calculated from the regression slope between coral and water $\mathrm{Ba} / \mathrm{Ca}$ with an intercept set at zero. The choice of $\mathrm{Sr} / \mathrm{Ca}$ temperature dependence for the CCA correction results in a maximum change of 0.1 in the $\mathrm{K}_{\mathrm{Ba}}$. This represents approximately $5 \%$ and $6 \%$ of the low and high temperature average $\mathrm{K}_{\mathrm{Ba}}$, respectively, and is similar to the $\mathrm{K}_{\mathrm{Ba}}$ standard error, as calculated from the linear regressions. In these experiments, the distribution coefficients were: $27.7^{\circ}$ $\mathrm{C}, \mathrm{K}_{\mathrm{Ba}}=1.73(1.69-1.77$, 95\% confidence interval $(\mathrm{CI})$ ), at $24.6^{\circ} \mathrm{C}, \mathrm{K}_{\mathrm{Ba}}=1.79(1.73-1.84,95 \% \mathrm{CI})$ and at $22.5^{\circ}$ $\mathrm{C}, \mathrm{K}_{\mathrm{Ba}}=1.88(1.81-1.95,95 \% \mathrm{CI})$. The $95 \%$ confidence intervals overlap due to the large range in polyp $\mathrm{Ba} / \mathrm{Ca}$. Lea et al. (1989) report lower $\mathrm{K}_{\mathrm{Ba}}$ values for mature colo- nies of Diploria labyrinthiformis (Bermuda) and Montastrea annularis (Bermuda) $\left(\mathrm{K}_{\mathrm{Ba}}=1.27 \pm 0.03\right)$ and for Pavona Clavus (Galapagos) $\left(\mathrm{K}_{\mathrm{Ba}}=1.41 \pm 0.14\right)$. The temperature dependence of the distribution coefficient for the $F$. fragum polyps falls along this regression line (Fig. 4a):

$\mathrm{K}_{B a}=2.514 \pm 0.190-0.02865 \pm 0.01487 T$

where $T$ is temperature in ${ }^{\circ} \mathrm{C}$. The experimentally precipitated inorganic aragonite in Gaetani and Cohen (2006) displays a greater temperature dependence than we observe for the Favia polyps or reported in Dietzel et al. (2004) (also in DeCarlo et al. (2015); see discussion below). Over the temperature range used in these experiments $\left(22.5-27.7^{\circ} \mathrm{C}\right)$, Dietzel et al. (2004) predicts a decrease in $\mathrm{K}_{\mathrm{Ba}}$ of 0.19 , DeCarlo et al. (2015) predicts a 0.22 decrease, and 


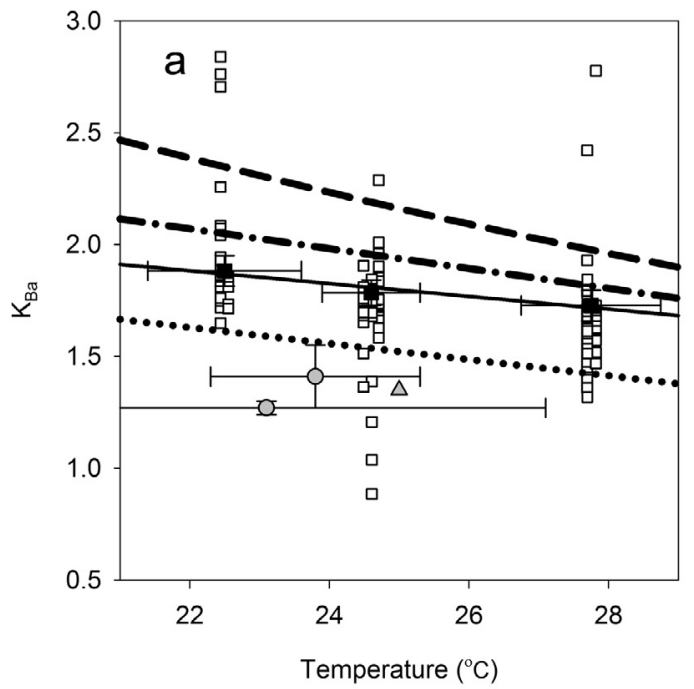

\begin{tabular}{|c|c|}
\hline$\square$ & This study, individual $\mathrm{K}_{\mathrm{Ba}}$ \\
\hline $\mathbf{\square}$ & This study, experimental $\mathrm{K}_{\mathrm{Ba}}$ \\
\hline 0 & Lea et al. 1989 \\
\hline$\triangle$ & Holcomb et al. 2010 \\
\hline--- & Gaetani and Cohen 2006 \\
\hline$\bullet \bullet \bullet \cdots \cdots \cdots \bullet$ & Dietzel et al. 2004 \\
\hline - - - • & DeCarlo et al. 2015/Holcomb et al. 2016 \\
\hline
\end{tabular}

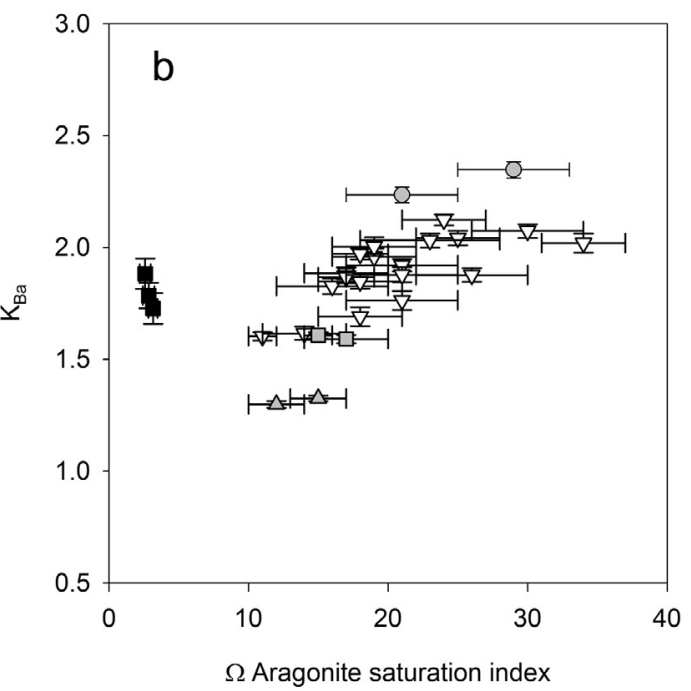

Fig. 4. (a) Temperature dependence of the Ba distribution coefficient $\left(\mathrm{K}_{\mathrm{Ba}}\right)$ for the Favia fragum corallites grown in culture as well as three abiogenic $\mathrm{K}_{\mathrm{Ba}}$ temperature dependences. Values for Lea et al. (1989) M. annularis (Bermuda) and P. Clavus (Galapagos) are also shown. For this experiment, $\mathrm{K}_{\mathrm{Ba}}$ at each temperature was calculated from the slope of corrected coral $\mathrm{Ba} / \mathrm{Ca}$ versus water $\mathrm{Ba} / \mathrm{Ca}$; $\mathrm{K}_{\mathrm{Ba}}$ error bars are the $95 \%$ confidence interval for the slope and temperature error bars represent the standard deviation during the experiment. $\mathrm{K}_{\mathrm{Ba}}$ calculated for each individual is also shown. The best-fit line (solid) is shown for the experimental distribution coefficient-temperature relationship: $\mathrm{K}_{\mathrm{Ba}}=2.514-0.02865 T\left(T\right.$ in $\left.{ }^{\circ} \mathrm{C}\right)$. (b) Abiogenic aragonite $\mathrm{K}_{\mathrm{Ba}}$ values vary as a function of aragonite saturation state (data from DeCarlo et al. (2015) and Holcomb et al. (2016) as described in the text). The F. fragum $\mathrm{K}_{\mathrm{Ba}}$ fall off this relationship, likely as a result of modification of calcifying fluid, as saturation state is shown for the bulk aquaria water.

Gaetani and Cohen (2006) predict a decrease of 0.37, compared to the 0.15 reduction that we observe in the Favia experiment.

\subsubsection{Precipitation rate and aragonite saturation state influence on $K_{B a}$}

In addition to temperature, elemental partitioning in aragonite has been related to other variables, such as calcification rate (Reynaud et al., 2007), extension rate (Pingitore et al., 1989; Saenger et al., 2008), aragonite saturation state (Kleypas et al., 1999; DeCarlo et al., 2015), and Rayleigh fractionation (Gaetani and Cohen, 2006). In these experiments, calcification rate, temperature, and aragonite saturation index are linked since we observed an increase in calcification at higher temperatures and saturation states, as reported previously (F. fragum, Barkley, 2011; Stylophora pistillata, Reynaud et al., 2003; Cladocora caespitosa, Rodolfo-Metalpa et al., 2008), although evidence has been presented elsewhere for a decline in calcification at the highest temperature used in these experiments $\left(27.7^{\circ} \mathrm{C}\right.$, Galaxea fascicularis and Dendrophyllia, Marshall and Clode, 2004). This increase in calcification at higher temperatures is potentially due to higher efficiency in the enzyme-regulated processes associated with calcification at increased temperatures, although species dependence cannot be ruled out (Marshall and Clode, 2004).

$\mathrm{K}_{\mathrm{Ba}}$ has been shown to increase concurrent with precipitation rates (Cohen and Gaetani, 2010). To explore the potential impact of calcification rate on $\mathrm{Ba}$ partitioning, we can compare the $F$. fragum experiment results to inorganic aragonite precipitation experiments (Dietzel et al., 2004; Gaetani and Cohen, 2006; Holcomb et al., 2010). In this study, the $\mathrm{K}_{\mathrm{Ba}}$ was calculated for each individual or grouped sample (see Methods) and compared to the calcification rate determined for that individual or grouped sample. In addition, we calculated $\mathrm{K}_{\mathrm{Ba}}$ from the abiogenic experiments described in DeCarlo et al. (2015) and Holcomb et al. (2016). We did this by using the measurements of the aragonite $\mathrm{Ba} / \mathrm{Ca}$ from Holcomb et al, (2016), the fluid [Ca] from DeCarlo et al. (2015), the local seawater $\mathrm{Ba} / \mathrm{Ca}$ from Gaetani and Cohen (2006), and following the partitioning calculations described in DeCarlo et al. (2015).

The coral $\mathrm{K}_{\mathrm{Ba}}$ values reported here are higher than those determined for inorganic aragonite reported by Dietzel et al. (2004) and Holcomb et al. (2010), but less than the values predicted by Gaetani and Cohen (2006) or calculated from DeCarlo et al. (2015) and Holcomb et al. (2016) 
(Fig. 4a). These experiments induced precipitation by creating supersaturated conditions with respect to aragonite. The experimental study design resulted in varying precipitation rates for each study: Dietzel et al., 2004 reports $\sim 10 \mathrm{mg} \mathrm{d}^{-1}, 40-70 \mathrm{mg} \mathrm{d}^{-1}$ reported by Gaetani and Cohen (2006) and DeCarlo et al. (2015) ranged from 50 to $500 \mathrm{mg} \mathrm{d}^{-1}$ (170 average). The growth rate in the Holcomb et al. experiment is not reported, although Cohen and Gaetani (2010) indicate that it was lower than 40 $70 \mathrm{mg} \mathrm{d}^{-1}$. In this study, precipitation rates for $F$. fragum in each treatment averaged from 1 to $7 \mathrm{mg} \mathrm{d}^{-1}$. Precipitation rate does not appear to explain the higher $\mathrm{K}_{\mathrm{Ba}}$ reported here compared to the abiogenic experiments. Note that while precipitation rate and distribution coefficient are both correlated to temperature in this experiment, there is no correlation between calcification rate and $\mathrm{K}_{\mathrm{Ba}}\left(r^{2}=0.01\right)$. While it is possible the range in precipitation rates in the current culture experiments is too small compared to the individual polyp variability to discern a precipitation rate dependence on $\mathrm{K}_{\mathrm{Ba}}$, calcification rate does not appear to drive changes in $\mathrm{K}_{\mathrm{Ba}}$.

Coral biomineralization processes may drive $\mathrm{Ba} / \mathrm{Ca}$ variability in our experiments. Corals precipitate their skeletons from a calcifying fluid that is supplied by seawater, but is isolated, or semi-isolated, with respect to the external seawater environment (Cohen and McConnaughey, 2003; Venn et al., 2011; Gagnon et al., 2012). Precipitation of aragonite from an isolated reservoir modifies the elemental composition of the calcifying fluid by raising $\mathrm{pH}$, effectively elevating the aragonite saturation state (Al-Horani et al., 2003; Venn et al., 2013). During this process, elements with $\mathrm{K}_{\mathrm{i}}>1$ (such as $\mathrm{Ba}$ ) are depleted relative to $\mathrm{Ca}$ in the coral calcifying fluid as precipitation proceeds from an isolated reservoir of fluid. Greater precipitation rates will therefore decrease the $\mathrm{Ba} / \mathrm{Ca}$ ratio of the calcifying fluid and the $\mathrm{Ba} / \mathrm{Ca}$ ratio of the coral skeleton precipitated from the fluid. Gaetani et al. (2011) described this as a Rayleigh fractionation process and found that the mass fraction of aragonite precipitated from the fluid increases (i.e. greater extent of precipitation) with increasing temperature. In addition, abiotic aragonite experiments have shown an increase in $\mathrm{K}_{\mathrm{Ba}}$ with increasing aragonite saturation state (Fig. 4b, Supplemental Table 3: $\mathrm{K}_{\mathrm{Ba}}$ calculated according to DeCarlo et al. (2015) from fluid [Ca] (DeCarlo et al., 2015), dissolved $\mathrm{Ba} / \mathrm{Ca}$ ratio (Gaetani and Cohen, 2006), and aragonite $\mathrm{Ba} / \mathrm{Ca}$ (Holcomb et al., 2016)). The $F$. fragum results fall off of the inorganic relationship, though, however saturation state is reported for the bulk seawater, not the calcifying fluid, which is likely higher. Variability in calcifying fluid chemistry and precipitation efficiency could potentially explain the large variability in coral $\mathrm{Ba} / \mathrm{Ca}$ and individual $\mathrm{K}_{\mathrm{Ba}}$ seen here, as well as contribute to the temperature dependence of $\mathrm{K}_{\mathrm{Ba}}$ that we observed. However, these influences cannot be resolved in this study.

\section{IMPLICATIONS FOR CORAL BA/CA AS A PALEOPROXY}

Through coral culture work we have shown that corals incorporate $\mathrm{Ba}$ in direct proportion to seawater concentrations up to $>400 \mathrm{nmol} \mathrm{kg}^{-1}$. Based on the distribution coef- ficient temperature dependence found here, the potential influence of temperature on coral $\mathrm{Ba} / \mathrm{Ca}$ ratios from 20 to $28^{\circ} \mathrm{C}$ in constant coastal ocean $\mathrm{Ba}$ concentrations of $50 \mathrm{nmol} \mathrm{kg}^{-1}$ would be $1.1 \mu \mathrm{mol} \mathrm{mol}{ }^{-1}$, or $\sim 13 \%$ increase corresponding to cooler temperatures. Peak $\mathrm{Ba} / \mathrm{Ca}$ ratios have been reported that are much greater than this, for example peak values of $12-17 \mu \mathrm{mol} \mathrm{mol}^{-1}$, attributed to river discharge to the Great Barrier Reef (Sinclair and McCulloch, 2004); 6-15 $\mu \mathrm{mol} \mathrm{mol}^{-1}$ attributed to upwelling in the Red Sea (Tudhope et al., 1996); and 8$18 \mu \mathrm{mol} \mathrm{mol}^{-1}$, attributed to sediment input in Hawaii (Prouty et al., 2010) (see Table 1). The partition coefficient temperature dependence is not sufficient to explain such large coral $\mathrm{Ba} / \mathrm{Ca}$ peaks. If these increases in coral $\mathrm{Ba} / \mathrm{Ca}$ are due primarily to changes in water chemistry, then elevated coastal ocean $\mathrm{Ba}$ concentrations must be sustained over the time period that corresponds to coral calcification. There is less evidence for large, temporally-sustained coastal ocean Ba concentrations of $80-140 \mathrm{nmol} \mathrm{kg}^{-1}$, or higher, to support the large coral $\mathrm{Ba} / \mathrm{Ca}$ peaks identified in Table 1. Typical coastal ocean $\mathrm{Ba}$ range from 40 to $75 \mathrm{nmol} \mathrm{kg}{ }^{-1}$, and are dependent on external dissolved $\mathrm{Ba}$ inputs and water residence times (Shaw et al., 1998; Gonneea et al., 2014). In addition, oceanic Ba cycling between the dissolved and particulate phase is controlled in part by productivity through precipitation of barite $\left(\mathrm{BaSO}_{4}\right)$ in decomposing organic matter and ultimately burial in sediments (Dehairs et al., 1980; Ganeshram et al., 2003). However, it is unlikely that this process will modify coastal ocean Ba concentrations to sufficiently explain the commonly observed annual cycle in coral $\mathrm{Ba} / \mathrm{Ca}$. Finally, the organic matter associated with the coral polyp is highly enriched in $\mathrm{Ba}$, which is removed prior to analysis through oxidation of sample material (Lea and Boyle, 1993). While there is some evidence that organic matter is preserved within the skeleton (Ingalls et al., 2003), it is not known if this organic matter contributes to coral skeletal $\mathrm{Ba} / \mathrm{Ca}$ below the polyp layer. Given the current uncertainty in how Rayleigh fractionation, calcification rate, extension rate, and saturation state affect coral $\mathrm{Ba} / \mathrm{Ca}$ ratios, relating coral $\mathrm{Ba} / \mathrm{Ca}$ paleo records to changes in seawater $\mathrm{Ba} / \mathrm{Ca}$ should be approached with caution. Finally, it is necessary to quantify natural variability in ocean $\mathrm{Ba}$ concentrations across appropriate temporal scales in response to the various environmental conditions for which $\mathrm{Ba}$ has been invoked as a useful tracer.

\section{ACKNOWLEDGEMENTS}

Samantha de Putron hosted the coral growth experiments at BIOS. Liz Drenkard guided the coral culturing experiments, while Alice Zicht assisted with aquaria maintenance. DIC and alkalinity measurements were carried out in the laboratories of Daniel McCorkle and William Martin at WHOI. Sean Sylva assisted with Ca measurements. M.E.G. was supported by a NDSEG graduate fellowship. Funding for this research came from the NSF Chemical Oceanography program (OCE-0751525) and the Coastal Ocean Institute, the Ocean and Climate Change Institute and the Ocean Ventures Fund at Woods Hole Oceanographic Institution. Any use of trade, firm or product names is for descriptive purposes only and does not imply endorsement by the U.S. Government. 


\section{APPENDIX A. SUPPLEMENTARY MATERIAL}

Supplementary data associated with this article can be found, in the online version, at http://dx.doi.org/10.1016/ j.gca.2017.04.006.

\section{REFERENCES}

Al-Horani F. A., Al-Moghrabi S. M. and De Beer D. (2003) The mechanism of calcification and its relation to photosynthesis and respiration in the scleractinian coral Galaxea fascicularis. Mar. Biol. 142, 419-426.

Alibert C. and Kinsley L. (2008) A 170-year Sr/Ca and Ba/Ca coral record from the western Pacific warm pool: 1 . What can we learn from an unusual coral record? J. Geophys. Res.-Oceans 113. http://dx.doi.org/10.1029/2006jc003979.

Alibert C., Kinsley L., Fallon S. J., McCulloch M. T., Berkelmans R. and McAllister F. (2003) Source of trace element variability in Great Barrier Reef corals affected by the Burdekin flood plumes. Geochim. Cosmochim. Acta 67, 231-246.

Barkley H. C. (2011) Establishing Links Between Basin-scale Climate and the Growth of Atlantic Corals: The Effect of Temperature and Feeding on Favia fragum. Ecology and Evolutionary Biology Department, Princeton University, p. 96.

Bath G. E., Thorrold S. R., Jones C. M., Campana S. E., McLaren J. W. and Lam J. W. H. (2000) Strontium and barium uptake in aragonitic otoliths of marine fish. Geochim. Cosmochim. Acta 64, 1705-1714.

Busenberg E. and Plummer L. N. (1986) A comparative study of the dissolution and crystal growth kinetics of calcite and aragonite. In Studies in Diagenesis, vol. 1578 (ed. F. A. Mumpton). U.S. Geological Survey Bulletin, pp. 139-168.

Carriquiry J. D. and Horta-Puga G. (2010) The Ba/Ca record of corals from the Southern Gulf of Mexico: contributions from land-use changes, fluvial discharge and oil-drilling muds. Mar. Pollut. Bull. 60, 1625-1630.

Chen T. R., Yu K. F., Li S., Chen T. G. and Shi Q. (2011) Anomalous $\mathrm{Ba} / \mathrm{Ca}$ signals associated with low temperature stresses in Porities corals from Daya Bay, northern South Cina Sea. J. Environ. Sci. 23, 1452-1459.

Cohen A. L. and Gaetani G. A. (2010) Ion partitioning and the geochemistry of coral skeletons: solving the mystery of the "Vital Effect". In On Partitioning in Low Temperature Aqueous Systems: From Fundamentals to Applications in Climate Proxies and Environmental Geochemistry (eds. M. Prieto and H. Stoll). European Mineralogical Union, Notes in Mineralogy.

Cohen A. L. and Holcomb M. (2009) Why corals care about ocean acidification: uncovering the mechanism. Oceanography 22, $118-127$.

Cohen A. L. and McConnaughey T. A. (2003) Geochemical perspectives on coral mineralization. Rev. Mineral. Geochem. 54, 151-187.

Corrége T., Delcroix T., Recy J., Beck W., Cabioch G. and Le Cornec F. (2000) Evidence for stronger El Nino-Southern Oscillation (ENSO) events in a mid-Holocene massive coral. Paleoceanography 15, 465-470.

de Putron S. J., McCorkle D. C., Cohen A. L. and Dillon A. B. (2011) The impact of seawater saturation state and bicarbonate ion concentration on calcification by new recruits of two Atlantic corals. Coral Reefs 30, 321-328.

DeCarlo T. M., Gaetani G. A., Holcomb M. and Cohen A. L. (2015) Experimental determination of factors controlling U/Ca of aragonite precipitated from seawater: Implications for interpreting coral skeleton. Geochim. Cosmochim. Acta 162, $151-165$.
Dehairs F., Chesseleet R. and Jedwab J. (1980) Discrete suspended particles of barite and the barium cycling in the open ocean. Earth Planet. Sci. Lett. 49, 528-550.

Dickson A. and Millero F. (1987) A comparison of the equilibrium constants for the dissociation of carbonic acid in seawater media. Deep Sea Res. Part A 34, 1733-1743.

Dietzel M., Gussone N. and Eisenhauer A. (2004) Co-precipitation of $\mathrm{Sr}^{2+}$ and $\mathrm{Ba}^{2+}$ with aragonite by membrane diffusion of $\mathrm{CO}_{2}$ between 10 and $50^{\circ} \mathrm{C}$. Chem. Geol. 203, 139-151.

Drenkard E. J., Cohen A. L., McCorkle D. C., de Putron S. J., Starczak V. R. and Zicht A. E. (2013) Calcification by juvenile corals under heterotrophy and elevated $\mathrm{CO}_{2}$. Coral Reefs. http://dx.doi.org/10.1007/s00338-00013-0102100335.

Elsdon T. S. and Gillanders B. M. (2003) Relationship between water and otolith elemental concentrations in juvenile black bream Acanthopagrus butcheri. Mar. Ecol. Prog. Ser. 260, 263 272.

Fallon S. J., McCulloch M. T., van Woesik R. and Sinclair D. J. (1999) Corals at their latitudinal limits: laser ablation trace element systematics in Porites from Shirigai Bay, Japan. Earth Planet. Sci. Lett. 172, 221-238.

Fassett J. D. and Paulsen P. J. (1989) Isotope dilution mass spectrometry for accurate elemental analysis. Anal. Chem. 61, $643 \mathrm{~A}-649 \mathrm{~A}$

Felis T., Lohmann G., Kuhnert H., Lorenz S. J., Scholz D., Patzold J., Al-Rousan S. A. and Al-Moghrabi S. M. (2004) Increased seasonality in Middle East temperatures during the last interglacial period. Nature 429, 164-168.

Fleitmann D., Dunbar R. B., McCulloch M., Mudelsee M., Vuille M., McClanahan T. R., Cole J. E. and Eggins S. (2007) East African soil erosion recorded in a 300 year old coral colony from Kenya. Geophys. Res. Lett. 34. http://dx.doi.org/10.1029/ $2006 \mathrm{~g} 1028525$.

Gaetani G. A. and Cohen A. L. (2006) Element partitioning during precipitation of aragonite from seawater: a framework for understanding paleoproxies. Geochim. Cosmochim. Acta 70, 4617-4634.

Gaetani G. A., Cohen A. L., Wang Z. and Crusius J. (2011) Rayleigh-based, multi-element coral thermometry: a biomineralization approach to developing climate proxies. Geochim. Cosmochim. Acta 75, 1920-1932.

Gagnon A. C., Adkins J. F. and Erez J. (2012) Seawater transport during coral biomineralization. Earth Planet. Sci. Lett. 329, $150-161$.

Gaillardet J., Viers J. and Dupre B. (2003) 5.09 - Trace elements in river waters. In Treatise on Geochemistry (eds. D. H. Heinrich and K. T. Karl). Pergamon, Oxford, pp. 225-272.

Ganeshram R. S., François R., Commeau J. and Brown-Leger S. L. (2003) An experimental investigation of barite in seawater. Geochim. Cosmochim. Acta 67, 2599-2605.

Gonneea M. E., Charette M. A., Liu Q., Herrera-Silveira J. A. and Morales-Ojeda S. M. (2014) Trace element geochemistry of groundwater in a karst subterranean estuary (Yucatan Peninsula, Mexico). Geochim. Cosmochim. Acta 132, 31-49.

Goodbody-Gringley G. and de Putron S. J. (2009) Planulation patterns of the brooding coral Favia fragum (Esper) in Bermuda. Coral Reefs 28, 959-963.

Holcomb M. C., McCorkle D. C. and Cohen A. L. (2010) Longterm effects of nutrient and $\mathrm{CO}_{2}$ enrichment on the temperate coral Astrangia poculata (Ellis and Solander 1786). J. Exp. Mar. Biol. Ecol. 286, 27-33.

Holcomb M. C., DeCarlo T. M., Gaetani G. A. and McCulloch M. (2016) Factors affection $\mathrm{B} / \mathrm{Ca}$ ratios in synthetic aragonite. Chem. Geol. 437, 67-76. 
Horta-Puga G. and Carriquiry J. D. (2012) Coral Ba/Ca molar ratios as a proxy of precipitation in the northern Yucatan Peninsula, Mexico. Appl. Geochem. 27, 1579-1586.

Ingalls A. E., Lee C. and Druffel E. R. M. (2003) Preservation of organic matter in mound-forming coral skeletons. Geochim. Cosmochim. Acta 67(2827), 2827-2841.

Jupiter S., Roff G., Marion G., Henderson M., Schrameyer V., McCulloch M. and Hoegh-Guldberg O. (2008) Linkages between coral assemblages and coral proxies of terrestrial exposure along a cross-shelf gradient on the southern Great Barrier Reef. Coral Reefs 27, 887-903.

Kleypas J. A., Buddemeier R. W., Archer D., Gattuso J. P., Langdon C. and Opdyke B. N. (1999) Geochemical consequences of increased atmospheric carbon dioxide on coral reefs. Science 284, 118-120.

Lea D. W. and Boyle E. A. (1993) Determination of carbonatebound barium in foraminifera and corals by isotope dilution plasma-mass spectrometry. Chem. Geol. 103, 73-84.

Lea D. W. and Spero H. J. (1992) Experimental-determination of barium uptake in shells of the planktonic-foraminifera Orbulina-universa at $22^{\circ} \mathrm{C}$. Geochim. Cosmochim. Acta 56, 26732680.

Lea D. W., Shen G. T. and Boyle E. A. (1989) Coralline barium records temporal variability in Equatorial Pacific upwelling. Nature 340, 373-376.

Lewis, E., Wallace, D., 1998. Program developed for CO2 system calculations. ORNL/CDIAC-105, Carbon Dioxide Information Analysis Center Oak Ridge Natl Lab. US Dept of Energy, Oak Ridge, TN.

Marshall A. T. and Clode P. (2004) Calcification rate and the effect of temperature in a zooxanthellate and an azooxanthellate scleractinian reef coral. Coral Reefs 23, 218-224.

McCulloch M., Fallon S., Wyndham T., Hendy E., Lough J. and Barnes D. (2003) Coral record of increased sediment flux to the inner Great Barrier Reef since European settlement. Nature 421, 727-730.

Mehrbach C., Culberso C. H., Hawley J. E. and Pytkowicx R. M. (1973) Measurement of apparent dissociation-constants of carbonic-acid in seawater at atmospheric-pressure. Limnol. Oceanogr. 18, 897-907.

Montaggioni L. F., Le Cornec F., Corrége T. and Cabioch G. (2006) Coral barium/calcium record of mid-Holocene upwelling activity in New Caledonia, South-West Pacific. Paleogeogr. Paleoclimatol. Paleoecol. 237, 436-455.

Moyer R. P., Grottoli A. G. and Olesik J. W. (2012) A multiproxy record of terrestrial inputs to the coastal ocean using minor and trace elements $(\mathrm{Ba} / \mathrm{Ca}, \mathrm{Mn} / \mathrm{Ca}, \mathrm{Y} / \mathrm{Ca})$ and carbon isotopes $(\delta \mathrm{C}$ $13, \Delta \mathrm{C}-14)$ in a nearshore coral from Puerto Rico. Paleoceanography 27. http://dx.doi.org/10.1029/2011pa002249.

Okai T., Suzuki A., Kawahata H., Terashima S. and Imai N. (2002) Preparation of a new Geological Survey of Japan geochemical reference material: Coral JCp-1. Geostand. Newsl. 26, 95-99.

Pelletier, G., Lewis, E., Wallace, D., 2007. $\mathrm{CO}_{2}$ sys.xls: A Calculator for the $\mathrm{CO}_{2}$ System in Seawater for Microsoft Excel/VBA. Washington State Department of Ecology/Brookhaven National Laboratory, Olympia, WA/Upton, NY, USA.

Pingitore N. E., Rangel Y. and Kwarteng A. (1989) Barium variation in Acropora-palmata and Montastrea-annularis. Coral Reefs 8, 31-36.

Prouty N. G., Field M. E., Stock J. D., Jupiter S. D. and McCulloch M. (2010) Coral Ba/Ca records of sediment input to the fringing reef of the southshore of Moloka'i, Hawai'i over the last several decades. Mar. Pollut. Bull. 60, 1822-1835.

Reuer M. K., Boyle E. A. and Cole J. E. (2003) A mid-twentieth century reduction in tropical upwelling inferred from coralline trace element proxies. Earth Planet. Sci. 210, 437-452.

Reynaud S., Leclercq N., Romaine-Lioud S., Ferrier-Pages C., Jaubert J. and Gattuso J. P. (2003) Interacting effects of $\mathrm{CO}_{2}$ partial pressure and temperature on photosynthesis and calcification in a scleractinian coral. Glob. Change Biol. 9, 1660 1668.

Reynaud S., Ferrier-Pages C., Meibom A., Mostefaoui S., Mortlock R., Fairbanks R. and Allemand D. (2007) Light and temperature effects on $\mathrm{Sr} / \mathrm{Ca}$ and $\mathrm{Mg} / \mathrm{Ca}$ ratios in the scleractinian coral Acropora sp.. Geochim. Cosmochim. Acta 71, 354 362.

Rodolfo-Metalpa R., Peirano A., Houlbreque F., Abbate M. and Ferrier-Pages C. (2008) Effects of temperature, light and heterotrophy on the growth rate and budding of the temperate coral Cladocora caespitosa. Coral Reefs 27, 17-25.

Saenger C., Cohen A. L., Oppo D. W. and Hubbard D. (2008) Interpreting sea surface temperature from strontium/calcium ratios in Montastrea corals: link with growth rate and implications for proxy reconstructions. Paleoceanography 23. http:// dx.doi.org/10.1029/2007pa001572.

Seo I., Lee Y. I., Watanabe T., Yamano H., Shimamura M., Yoo C. M. and Hyeong K. (2013) A skeletal Sr/Ca record preserved in Dipsastraea (Favia) speciosa and implications for coral $\mathrm{Sr} /$ $\mathrm{Ca}$ thermometry in mid-latitude regions. Geochem. Geophys. Geosyst. 14, 2873-2885.

Shaw T. J., Moore W. S., Kloepfer J. and Sochaski M. A. (1998) The flux of barium to the coastal waters of the southeastern USA: the importance of submarine groundwater discharge. Geochim. Cosmochim. Acta 62, 3047-3054.

Sinclair D. J. (2005) Non-river flood barium signals in the skeletons of corals from coastal Queensland, Australia. Earth Planet. Sci. Lett. 237, 354-369.

Sinclair D. J. and McCulloch M. T. (2004) Corals record low mobile barium concentrations in the Burdekin River during the 1974 flood: evidence for limited Ba supply to rivers? Paleogeogr. Paleoclimatol. Paleoecol. 214, 155-174.

Tudhope A. W., Lea D. W., Shimmield G. B., Chilcott C. P. and Head S. (1996) Monsoon climate and Arabian sea coastal upwelling recorded in massive corals from southern Oman. Palaios 11, 347-361.

Venn A., Tambutté E., Holcomb M., Allemand D. and Tambutté S. (2011) Live tissue imaging shows reef corals elevate $\mathrm{pH}$ under their calcifying tissue relative to seawater. PLOS ONE 6, e20013. http://dx.doi.org/10.1371/journal.pone.0020013.

Venn A. A., Tambutté E., Holcomb M., Laurent J., Allemand D. and Tambutté S. (2013) Impact of seawater acidification on $\mathrm{pH}$ at the tissue-skeleton interface and calcification on coral reefs. Geochim. Cosmochim. Acta 68, 1473-1488.

Wyndham T., McCulloch M., Fallon S. and Alibert C. (2004) High-resolution coral records of rare earth elements in coastal seawater: biogeochemical cycling and a new environmental proxy. Geochim. Cosmochim. Acta 68, 2067-2080.

Yoshinaga J., Nakama A., Morita M. and Edmonds J. S. (2000) Fish otolith reference material for quality assurance of chemical analyses. Mar. Chem. 69, 91-97.

Associate editor: Daniel Sinclair 